Nozima Pulatova. postdoctoral Institute of Retraining and Advanced Training of Education and Leadership Named after Abdulla Avloni, 100187, Uzbekistan, Tashkent, M. Uiugbek districk, st.Buyuk Ipak Yulu ORCID: 0000-0003-4325-7810

\title{
GOAL SETTING IN INNOVATIVE MANAGEMENT ACTIVITIES IN SECONDARY SCHOOLS
}

The article describes the problems and highlights their solutions in innovative management activities in secondary schools. New possible goals in innovative management of secondary school principals are shown.

Key words: Innovative management, innovation, innovative activities.

The concept of a goal in management is associated with the identification of its functional significance. If we consider management from the perspective of Cybernetics, this process is based on receiving feedback, without which neither management nor self-regulation of the cybernetic system is possible, such as the system «administration of an educational institution-pedagogical, school and parent collectives». It is well known that the better the feedback, the better the management process. It is crucial to clarify the purpose of the school administration's management activities.

Creating an optimal management system is associated with a targeted approach to the practice of solving the problems facing modern schools. To solve this problem, we need to clarify the essence of the concept of «goal». In philosophy, we find the following definitions. The goal is:

a) the final state to which the system aspires and which serves to organize its actions (B. S. Ukraintsev);

b) possible future state of the object (V. S. Tyukhtin);

c) the image of the desired future, the achievement of which is subject to human activity; ideal model of the desired future (L. V. Spirkin);

d) a mental image of what will be done (NL. Trubnikov);

e) anticipation in the mind of the result on the achievement of directed actions (Philosophical dictionary);

e) the achievement of certain amendments (J. Salkova). 
Considering the Genesis of the goals of modern school management leads us to the idea that the goal of management set for the administration of an educational institution is determined by the needs of society, depends on the spiritual and intellectual potential of society, and consists in achieving certain changes in the results of education. Goal setting in management is related to external and $\backslash$ internal conditions. To external conditions should include:

1) heterogeneity of management objects (teaching staff, student staff, administrative group, parent team, technical staff);

2) the status and features of the functioning of an educational institution (Lyceum, gymnasium, school-system, municipal comprehensive school; features of functioning - the work of the institution in the development mode);

3) determinism of the content of education by social order:

Internal conditions may include subjective position participants in the innovation process and the acquisition of individual personal experience in innovation. If the goal becomes a motive, an internal incentive becomes for activity, then the nature of this activity changes. In General, the study of goal setting conditions in management should be the subject of a separate study.

We find it interesting to interpret the goal as « anticipation in the mind of the result to achieve which actions are strictly directed, and it should reflect the perspective that is caused by the transfer of the institution to a higher level of development, which is possible on the basis oftransfer of the management object to the state of the subject of management activity» [2].

First of all, in our opinion, the target approach is manifested in the requirements for the content of education, which in its essence is a model of social order for the school. This is a goal set from the outside. To achieve this goal, it becomes important to clarify the question of who exactly acts as a social customer.

Any activity, both individual and collective, should always be aimed at achieving certain goals. Psychologists note that the structure of human activity includes actions-processes subordinate to a conscious goal [1]. The goal involves predicting the results of managed educational activities, which is why it has the property of being predictive.

For us, defining a goal means not only predicting the performance of an educational institution, but also identifying new approaches to school management and making optimal management decisions based on it. Thus, we approach the definition of the interaction of the goal set from the outside and the goal set by the subject in the process of activity. In this case, the subject is the teaching staff of an educational institution, which sets a goal, thereby determining the direction and content of its own activities.

The results of numerous psychological and pedagogical studies show that when setting goals, it is necessary to take into account the performance of two functions regulatory and motivational. The goal can regulate the activity in a specific 
professional field, if it is deeply understood and accepted in the personal plan. It can stimulate activity if it is available, understood and meets the interests of participants in the educational process. The predicted results can be achieved if the process of translating the objective meaning of the goal (from the outside) into a subjective meaning is carried out, and its acceptance by the subject of activity.

The complexity of goal setting lies in the significance of the school's goals, which was pointed out by B. C. Ilyin at the time. The scientist spoke about the goals in which «a change in knowledge and skills should be projected in unity with the development of a person, a complex of humanistic qualities: a cultured, educated, morally and politically permanent person...» [2].

Setting a management goal required us to set certain requirements for it. These requirements were based on the recommendations of Yu. K. Babansky [3], which were transformed by us taking into account the specifics of management. Goals should be: 1) quite tight, focusing on a maximum of possibilities of participants of educational process; 2) contribute to the achievement of predictable results; 3) aware of all participants in the educational process so that they become a guide to action; 4) specific-specific 5) flexible, allowing for changes in conditions and opportunities to achieve them.

At the same time, we took into account some of the requirements developed by N. V. Gizatulina. In particular, we felt it necessary to highlight the following requirements: 1) the purpose of each stage of the teaching process must have an end goal; 2) science-based goals for each stage to focus on the idea of levels of the generated quality; 3) the goals can be: actualization, consolidation or generalization of certain States of components, their relationships, qualities in General; 4) in the system of goals in relation to each state of the pedagogical process, parameters of the dominant influence can be identified based on the identified relationships of quality components, their hierarchy and the degree of manifestation of integral-forming functions of components [4].

We have compiled a set of requirements for a goal based on the requirements developed by Yu. K. Babansky and N. V. Gizatulina. The requirements should:

1) take into account the specifics and features of the educational space of the educational institution;

2) be understood by all participants of the educational process and be a guide to action;

3) be specific and focused on achieving optimal results by participants in the educational process;

4) include a system of flexible targets for each stage of the educational process, taking into account changes and opportunities to achieve results.

Obvious is the fact that a sense of purpose contributes to the process 'translating its objective meaning into a subjective meaning, acquiring it social, psychological and 
pedagogical significance. Only in this in this case, the management of the educational institution can:

1) Orient and take into account the real capabilities of participants in the educational process;

2) justify the requirements for the organization of the educational process and its participants;

3) be guided by clear criteria that define

effectiveness of educational process management and its implementation subjects;

4) optimally choose the forms and methods of intra-school control.

Setting a strategic goal that involves getting the forecast result provides for taking into account the specifics of the educational institution, the opportunities of participants in the educational process, and the time allocated for managerial influence. In this regard, we agree with the views of a.m. Saranov, N. K. Sergeev, $\mathrm{V}$. V. Serikov that it is necessary to take into account the principles of the educational institution in the new conditions. Among the most important principles that should be taken into account, we include: 1) implementation of a program-oriented approach to managing the development of education with a characteristic «tree of goals», a system of means to achieve them, and the logic of the process; 2) combination of theoretical and laboratory research of scientists with mass innovation of teachers; 3 ) combination in unity of the concept of stabilization and innovative search [4].».

Analysis of the content of the National education doctrine, normative documents, opinions of parents, University teachers, interests and needs of students allow us to determine priorities in the management of modern schools within the framework of the strategic goal.

The main task of the Russian educational policy today is to ensure the modern quality of education by preserving its fundamental nature and compliance with current and future trends the needs of the individual, society, and the state are impossible without the development of educational institutions. Therefore, the management of the process of development of an educational institution that leads to improving the quality of education is crucial in the administration's activities.

In our research, we adhere to the point of view of V. M. Polonsky, who believes that the quality of education is «a certain level of knowledge and skills, mental, physical and moral development achieved by graduates of an educational institution in accordance with the planned goals of training and education» [5].

In essence, this means that if the results achieved by students correspond to the set goals, predicted taking into account the potential development zone, then the education they receive is of high quality. 
To solve the problem of quality management, it is important to define the goal, means, result and the existing interdependence between them. At the same time, the means are considered as a process of achieving the predicted result. we can say that quality management of education is management by goals and results.»

Therefore, a management system should be created in which the goal acts as a systematizing factor. Therefore, it is legitimate to define the goal of management as the transfer of a managed system from one quality state to another, which is determined by the requirements of Social customers for the quality of students " education. Change the target settings in the management entail, as a consequence, organizational and managerial innovations.

\section{REFERENCES}

1. Tikhomirov O. K. Psychological mechanisms of goal formation, ed. Tikhomirov O. K-M. Nauka, 1977. - 259 s: Il.

2. Philosophical dictionary./ Under the editorship of I. T. Frolov, 4th ed. Moscow: Politiz-DAT, 1980. - 406 p.

3. Babansky Yu. K., Kharkiv V. F. on the optimality of pedagogical experiment. // Methods of scientific and pedagogical research: Collection of articles / Ed. by Yu. K. Babansky, b. C. ilina. -Publishing house Rostov n / D PED. in-t, 1972. P. 3-10.

4. Vereva V. I. self-Certification of schools. - M.: «Pedagogical search», 2000. $160 \mathrm{p}$.

5. Polonsky V. M. Dictionary of concepts and terms on the legislation of the Russian Federation on education. - M.: MIROS, 1995. - 79 p. 